\title{
A BRIEF REVIEW ON ZIKA VIRUS INFECTION
}

\author{
Maria Fernanda Rios Grassi*, Antônio Carlos Albuquerque Bandeira**, Luana Leandro Gois***, \\ Geraldo Gileno de Sá Oliveira \\ Corresponding author: Geraldo Gileno de Sá Oliveira - ggileno@bahia.fiocruz.br \\ * PhD, Researcher at the Oswaldo Cruz Foundation, Bahia, Brazil, Adjunct Professor at BAHIANA - School of Medicine and \\ Public Health \\ ** Aliança Hospital, Salvador, Brazil \\ *** Researcher at the Oswaldo Cruz Foundation, Brazil. BAHIANA - School of Medicine and Public Health, Salvador, Brazil \\ **** Researcher at the Oswaldo Cruz Foundation, Brazil
}

\begin{abstract}
Since isolation of Zika virus (ZIKV) in Uganda from Zika forest in the 1947, for sixty years the virus has caused only scattered human cases in Africa and Southeast Asia. From 2007, outbreaks with an increasing number of cases, including cases with neurological manifestations, have been occurring in Pacific islands. In 2015, ZIKV reached Brazil with an explosive number of cases and a severe neurological impact on fetuses and newborns. The natural history and several immunological aspects of ZIKV infection need to be characterized. In this review it is summarized the spread of ZIKV around the world and pointed out some gaps on the immunological knowledge related to the infection. The characterization of the immunodominant/protective immune response would contribute to vaccine and diagnosis tests development.
\end{abstract}

Keywords: Zika Virus; Epidemiology; Infection.

The Zika virus (ZIKV) was first isolated in 1947 from a Rhesus monkey, from the Zika forest in Uganda, in the context of a program for surveillance of yellow fever in primates.(1) The virus was subsequently isolated from humans in Nigeria in 1954. ${ }^{(2)}$ For decades, the occurrence of ZIKV infection in humans remained restricted to some countries in equatorial Africa and Asia, as a sporadic disease. However, in 2007, a major epidemic of ZIKV infection occurred at
Yap islands, one of four states that make up the Federated States of Micronesia, in the Pacific Ocean. A serological study estimated that almost $70 \%$ of the population was infected by the virus during the epidemic. (3) From 2007 to 2013, only few cases of ZIKV infection were reported in travelers returning from Africa or Southeast Asia. ${ }^{(4,5)}$ In October 2013, another outbreak was detected in French Polynesia with more than 300 confirmed cases of infection and about 29,000 
people (10\% of the population) sought medical services with symptoms suggestive of the disease. ${ }^{(6)}$
The virus subsequently spread to other areas of the Pacific, including the Cook Islands, New Caledonia and Easter Island. ${ }^{(7,8)}$ (Figure 1).

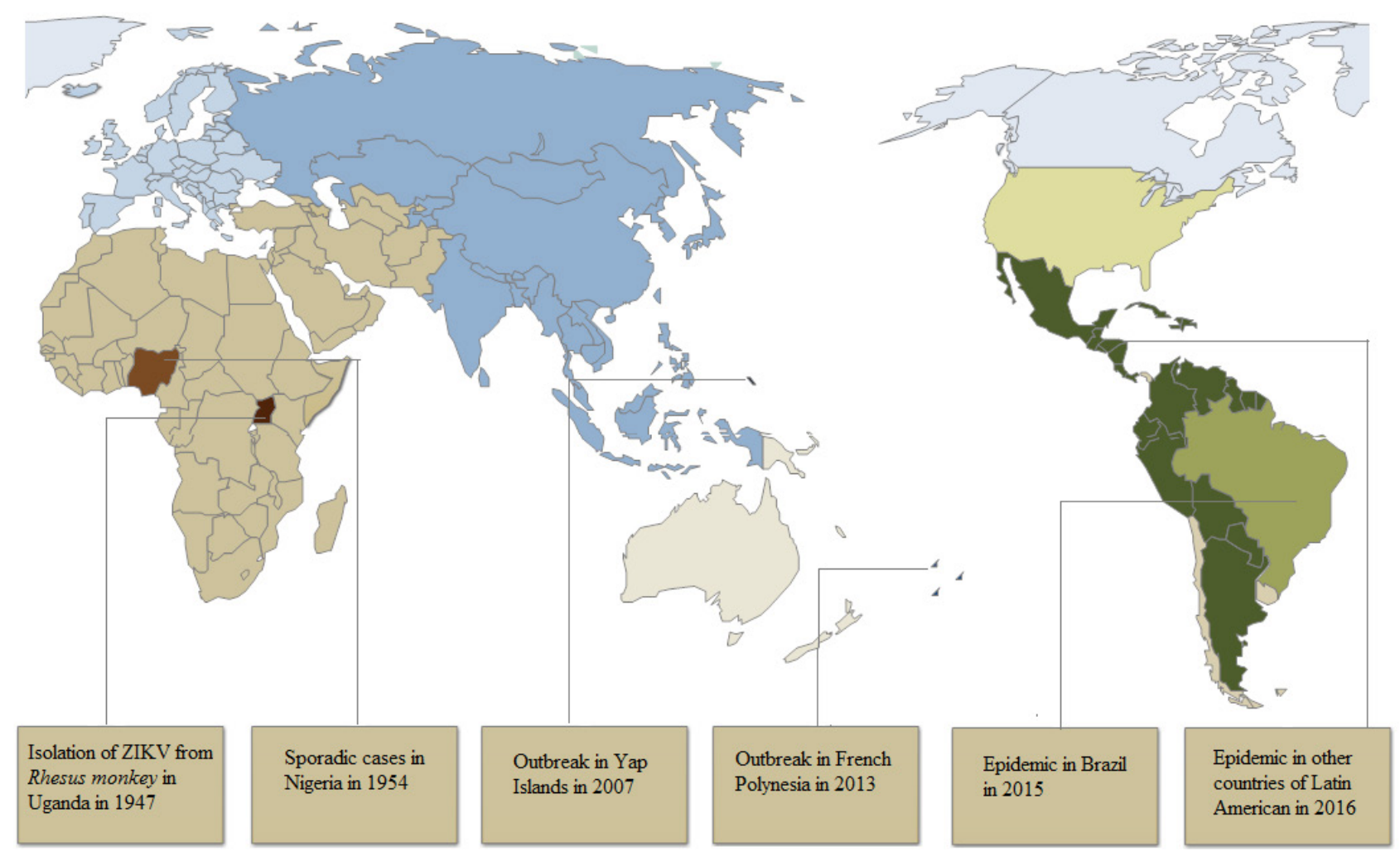

Figure 1 - Spread of Zika virus from Zika Forest in Uganda to Americas

In the Americas, the virus was first detected in Brazil in patients from Camaçari, Bahia, on March $26^{\text {th }} 2015^{(9)}$ and subsequently in other states in Brazil from May 2015..$^{(10)}$ In this country, the ZIKV disease spread to several states, resulting in the largest epidemic ever reported to date. It is estimated that between 440,000 and 1,300,000 individuals had the infection during the epidemic. ${ }^{(1)}$ By May 2016, 39 countries have reported autochthonous transmission of ZIKV (Argentina, Aruba, Barbados, Belize, Bolivia, Bonaire, Brazil, Colombia, Costa Rica, Cuba, Curaçao, Dominica, Dominican Republic, Ecuador, El Salvador, Granada, French Guyana, Guadaloupe, Guatemala, Guyana, Haiti, Honduras, Jamaica, Martinique, Mexico, Nicaragua, Panama, Paraguay, Peru, Puerto Rico, Saint Martin, Sint Maarten, Saint Vincent and Grenadines, Saint Lucia, Saint Barthelemy, Suriname, Trinidad and Tobago, US Virgin Islands, and Venezuela). ${ }^{(12)}$ The outbreak in Brazil was associated with an increase in the number of babies born with microcephaly, prompting World Health Organization (WHO) to declare by February 1st, 2016, epidemic by ZIKV be a public health emergency of international importance. ${ }^{(13)}$

The ZIKV is transmitted by different species Aedes mosquito and in Africa non-human primates were considered the main reservoir. Although viral transmission occurs mainly through the bite of Aedes mosquitoes, transmission by sexual, ${ }^{(14)}$ perinatal, ${ }^{(15)}$ and blood transfusion, ${ }^{(16)}$ have also been reported. In addition, the virus can be isolated in saliva and urine of individuals in the acute phase of infection. ${ }^{(15,17)}$

The ZIKV belongs to Flaviviridae family and genus Flavivirus. Viral particles have rounded shape that measure about $50 \mathrm{~nm}$ in diameter. These particles are composed of a positive single-stranded 
RNA, capsid and envelope. The genome $(10,794$ nucleotides) encodes 10 proteins, being 3 structural [envelope protein (E), precursor membrane (prM) and capsid (C)] and seven nonstructural proteins


The proteins $\mathrm{M}, \mathrm{NS} 2 \mathrm{a}, \mathrm{NS}_{2} \mathrm{~B}, \mathrm{NS}_{4} \mathrm{~A}, \mathrm{NS}_{4} \mathrm{~B}$ are located almost exclusively in lipid bilayer of membranes, either in viral envelope (prM) or endoplasmic reticulum of the host cell (NS2a, NS2 $\mathrm{B}, \mathrm{NS}_{4} \mathrm{~A}$, $N S_{4} B$ ), while proteins $E, C, N S_{1}, N S_{3}$ and $N_{5}$ do not display a transmembrane domain or the transmembrane domain(s) represent only a small part of the whole polypeptide chain. E protein, which is the major protein of the viral envelope, has 2 transmembrane and 3 extra-membrane domains, probably participates in binding and entry of virus into host cells. Nonstructural protein NS1 (participates in viral genome replication), NS3 (helicase/protease) and NS5 (RNA-dependent RNA polymerase) are involved in viral replication and/or assembly that occurs in association with vesicles in the endoplasmic reticulum. ${ }^{(19)}$ Comparison of amino acid sequences of orthologous proteins from ZIKV dengue virus (DENV, also a member of Flaviviridae family and Flavivirus genus) reveals an identity of about $60 \%$.

Diagnosis of ZIKV infection is based on clinical signs and detection of viral RNA in serum using reverse transcription PCR (RT-PCR). Although specific IgM could be detected by ELISA, few laboratories have this capability. Diagnostic is still hampered due to low viremia and cross-reactivity of antibodies produced during ZIKV infection and exposure to antigens of other members of Flavivirus genus (including dengue and yellow fever), and requires confirmation by neutralization assays plate. ${ }^{(20)}$

The vast majority of cases of ZIKV infection are asymptomatic or show a dengue fever-like syndrome, unlike chikungunya virus infection that is symptomatic in a significant number of cases. ${ }^{(3)}$ In symptomatic cases, the most common signs and symptoms of infection are maculopapular pruritic rash, variable fever, transient arthralgia, myalgia, headache and conjunctivitis; edema, sore throat, cough and vomiting occur less frequently. ${ }^{(21)}$
Following ZIKV disease epidemic in French Polynesia an increase in the number of cases of Guillain-Barré syndrome and other neurological condition have been observed, which were attributed to complications of infection. (6) In Brazil, the ZIKV disease epidemic coincided with an explosive microcephaly epidemic in newborns, with the first cases diagnosed about six months after the virus detection in the country. Until May 28, 2016, the Brazilian Ministry of Health had confirmed microcephaly and other disorders of the central nervous system in 1,489 cases. ${ }^{(22)}$ ZIKV has been detected in the amniotic fluid, brain or spinal fluid of 41 babies and fetuses born with microcephaly. ${ }^{(23)}$ The Brazilian Ministry of Health recognized an association between microcephaly and ZIKV infection in November, 2015. ${ }^{(24)}$

Congenital malformations, that result in microcephaly has a complex etiology and probably several predisposing factors. They may be related to fetal exposure to high viral load, a more pathogenic viral isolate, or genetic and/or environmental factors, comorbidities, prior infections with other infectious agents. Many other pathogens, including cytomegalovirus, Toxoplasma gondii, herpes virus, Treponema pallidum can harm fetuses and cause congenital malformations. Among species of Flavivirus genus, previously, only rare reports has linked encephalitis West Nile virus to changes in the nervous system of fetuses. ${ }^{(25)}$

The pathogenesis of severe cases of ZIKV infection, especially Guillain-Barré syndrome and microcephaly, is still unknown. The evidence available so far indicates an association between infection with ZIKV and the occurrence of microcephaly. However, it is not clear which factors are linked to this outcome, such as viral load, host factors, time of infection or the presence of other comorbidities. The role of the immune response in protection or in association with these complications remains to be investigated. One important question to be addresses is whether the presence of coinfections or antibodies to prior Flavivirus or Alphavirus infections (like dengue and chikungunya) could potentiate central nervous system damage. In relation to dengue, for example, a subsequent infection by 
a different virus subtype amplifies viral load and predisposes to more severe clinical manifestations of the disease, causing hemorrhagic dengue fever. Following DENV infection, most antibodies are directed against $E$ and $N S 1$ proteins, while specific $\mathrm{CD}_{4}+$ and $\mathrm{CD} 8+\mathrm{T}$ lymphocytes recognizes epitopes primarily on NS3 protein (DENV). ${ }^{(29-32)}$ So far there is no evidence that antibodies can promote increase in viral load and cause more severe cases during ZIKV infection as reported for secondary DENV infection. Immune response in the course of ZIKV infection has hardly been evaluated; therefore, there is still an important gap in this area of knowledge.

The natural history of ZIKV infection still needs to be better characterized. In addition, there are major gaps in the knowledge of the immune response developed in the course of infection. For example, it has not been determined yet: i) the kinetics and isotypes of antibodies associated with infection phases; ii) the frequency of development of neutralizing antibodies, iii) the existence of specific antibodies acting as infection facilitators, that would amplify the viral load, iv) the role of antibodies induced in prior exposition to other flaviviruses, and v) the occurrence of autoimmune reactions contributing to pathogenesis. The immunodominant and/or immune-protective ZIKA viral antigens as well as particular immunologic signatures of individuals with asymptomatic, classical and severe ZIKV infection as Guillan-Barré and congenital neurological defects remain to be defined.

The international scientific community has been making an effort to deal with this important public health problem by conducting studies on clinical and epidemiological aspects of the infection, development of accurate laboratory diagnosis, drugs and vaccines as well as vector control. Such an effort should contribute for controlling the ZIKV epidemic.

\section{REFERENCES}

1. Dick GW. Zika virus. II. Pathogenicity and physical properties. Trans R Soc Trop Med Hyg. 1952;46(5):521-534.

2. Macnamara FN. Zika virus: a report on three cases of human infection during an epidemic of jaundice in Nigeria. Trans R Soc Trop Med Hyg. 1954;48(2):139-145.

3. Duffy MR, Chen TH, Hancock WT, Powers AM, Kool JL, Lanciotti RS, et al. Zika virus outbreak on Yap Island, Federated States of Micronesia. N Eng J Med. 2009; 360(24):2536-2543.

4. Foy BD, Kobylinski KC, Chilson Foy JL, Blitvich BJ, Travassos da Rosa A, Haddow AD, et al. Probable non-vector-borne transmission of Zika virus, Colorado, USA. Emerg Infec Dis. 2011;17(5):880-882.

5. Kwong JC, Druce JD, Leder K. Zika virus infection acquired during brief travel to Indonesia. Am J Trop Med Hyg. 2013;89(3):516-517.

6. loos S, Mallet HP, Leparc Goffart I, Gauthier V, Cardoso T, Herida M. Current Zika virus epidemiology and recent epidemics. Med Mal Infect. 2014;44(7):302-307.

7. Musso D, Nilles EJ, Cao-Lormeau VM. Rapid spread of emerging Zika virus in the Pacific area. Clin Microbiol Infect. 2O14;2O(10):O595-596.

8. Roth A, Mercier A, Lepers C, Hoy D, Duituturaga $\mathrm{S}$, Benyon $\mathrm{E}$, et al. Concurrent outbreaks of dengue, chikungunya and Zika virus infections - an unprecedented epidemic wave of mosquitoborne viruses in the Pacific 2012-2014. Euro Surveill. 2014;19(41).

9. Campos GS, Bandeira AC, Sardi SI. Zika Virus Outbreak, Bahia, Brazil. Emerg Infec Dis. 2015;21(10):1885-1886.

10. Zanluca C, de Melo VC, Mosimann AL, dos Santos GI, dos Santos CN, Luz K. First report of autochthonous transmission of Zika virus in Brazil. Mem. Inst. Oswaldo Cruz. 2015;110(4):569-572.

11. European Centre for Disease Prevention and Control. Rapid risk assessment: Zika virus epidemic in the Americas: potential association with microcephaly and Guillain-Barré syndrome. Stockholm: ECDC; 2015. 
12. Pan American Health Organization / World Health Organization. Zika Epidemiological Update (Americas) - 16 June 2016. Washington, D.C.: PAHO/WHO; 2016 [cited 2016 May 26]. Available from: http://www.paho.org/hq/index. php?option=com_content\&view=article\&id=11599 \&ltemid=41691.

13. World Health Organization WHO statement on the first meeting of the International Health Regulations (2OO5)(IHR 2OO5) Emergency Committee on Zika virus and observed increase in neurological disorders and neonatal malformations. 1 Feb 2016. Available from: http://www.who.int/mediacentre/news/ statements/2016/1st-emergency-committeezika/en/

14. Oster AM, Brooks JT, Stryker JE, Kachur RE, Mead P, Pesik NT, et al. Interim Guidelines for Prevention of Sexual Transmission of Zika Virus United States, 2016. MMWR Morb Mortal Wkly Rep. 2016;65(5):12O-121.

15. Besnard M, Lastere S, Teissier A, Cao-Lormeau $\mathrm{V}$, Musso D. Evidence of perinatal transmission of Zika virus, French Polynesia, December 2013 and February 2O14. Euro Surveill. 2014;19(13).

16. Schnirring $L$. Brazil confirms blood-transfusion Zika; PAHO calls for global support. CIDRAP News; 2016 [cited 2016 05O22016]. Available from: http://www.cidrap.umn.edu/ newsperspective/2O16/O2/brazil-confirmsblood-transfusion-zika-paho-calls-global-support

17. Gourinat AC, O'Connor O, Calvez E, Goarant C, Dupont-Rouzeyrol M. Detection of Zika virus in urine. Emerg Infec Dis. 2015;21(1):84-86.

18. Lindenbach BD, Rice CM. Molecular biology of flaviviruses. Adv Virus Res. 2003;59:23-61.

19. Flavivirus. Viralzone News. 2O16. Available from: http://viralzone.expasy.org/all_by_species/24.html

2O. Charrel RN, Leparc-Goffart I, Pas S, de Lamballerie X, Koopmans M, Reusken C. State of knowledge on Zika virus for an adequate laboratory response [Submitted]. Bull World Health Organ. E-pub: 10 Feb 2016. doi: http:// dx.doi.org/10.2471/BLT.16.171207). 2016.

21. Hayes EB. Zika virus outside Africa. Emerg Infec Dis. 2009;15(9):1347-1350.
22. Ministério da Saúde (BR). Ministério da Saúde confirma 1.489 casos de microcefalia no país [Internet]. Ol jun. 2016. Available from: Portalsaude.saude.gov.br/index.php/cidadao/ principal/agencia-saude/23933-ministerio-dasaude-confirma-1-489-casos-de-microcefalia-nopais.

23. Ministério da Saúde (BR). Centro de Operações de Emergências em Saúde Pública. Monitoramento dos Casos de Microcefalia no Brasil. Informe Epidemiológico no.12. Semana Epidemiológica O5. Brasília; 2016.

24. Ministério da Saúde (BR). Ministério da Saúde confirma relação entre vírus Zika e microcefalia [Internet]. 28 nov. 2015. [cited 2015 Dec 6]. Available from: http://portalsaude.saude. gov.br/index.php/cidadao/principal/agenciasaude/21014-ministerio-da-saudeconfirmarelacao-entre-virus-zika-e-microcefalia.

25. Alpert SG, Fergerson J, Noel LP. Intrauterine West Nile virus: ocular and systemic findings. Am J Ophthalmol. 2003;136(4):733-735.

26. Hamel R, Dejarnac O, Wichit S, Ekchariyawat P, Neyret A, Luplertlop N, et al. Biology of Zika Virus Infection in Human Skin Cells. J Virol. 2015;89(17):8880-8896.

27. Tappe D, Perez-Giron JV, Zammarchi L, Rissland J, Ferreira DF, Jaenisch T, et al. Cytokine kinetics of Zika virus-infected patients from acute to reconvalescent phase. Med Microbiol Immunol. 2015;2O5(3):269-273.

28. Cardoso CW, Paploski IA, Kikuti M, Rodrigues MS, Silva MM, Campos GS, et al. Outbreak of Exanthematous IIlness Associated with Zika, Chikungunya, and Dengue Viruses, Salvador, Brazil. Emerg Infec Dis. 2015;21(12):2274-2276.

29. Appanna R, Huat TL, See LL, Tan PL, Vadivelu J, Devi S. Cross-reactive T-cell responses to the nonstructural regions of dengue viruses among dengue fever and dengue hemorrhagic fever patients in Malaysia. Clin Vaccine Immunol. 2007;14(8):969-977.

30. Lazaro-Olan L, Mellado-Sanchez G, GarciaCordero J, Escobar-Gutierrez A, SantosArgumedo L, et al. Analysis of antibody response in human dengue patients from the Mexican coast using recombinant antigens. Vector Borne Zoonotic Dis. 2008;8(1):69-79. 
31. Mathew A, Rothman AL. Understanding the contribution of cellular immunity to dengue disease pathogenesis. Immunol Rev. 2008;225:300-313.
32. Rothman AL. Dengue: defining protective versus pathologic immunity. J Clin Invest. 2004;113(7):946-951. 